The Australasian Accounting Business \& Finance Journal, September, 2008.

Wild: Sustainability Reporting in Fishing Industry Management. $\quad$ Vol. 2, No.3. Page 57.

\title{
SUSTAINABILITY REPORTING IN FISHING INDUSTRY MANAGEMENT - REGULATION VERSUS VOLUNTARISM
}

\author{
Susan Wild \\ Faculty of Business and Informatics \\ Central Queensland University/New Zealand International Campus \\ sue.wild@nzic.ac.nz
}

\begin{abstract}
A growing number of major corporations and industry organizations now overtly advocate the general concept of corporate social and environmental responsibility, commonly emphasising the 'business case' for such behaviour on the basis that it is 'good for business'. Many now report to their stakeholders on a voluntaristic basis a range of information regarding their impacts on the social and physical environment in which they operate.
\end{abstract}

Intrinsic to the business case model is the argument that an optimal balance between the needs of economic growth and the sustainable management of natural resources can best be attained through the conventional mechanisms of corporate governance and voluntary corporate activity, rather than by imposition of governmental regulation. This view implies, however, that where the exigencies of environmental sustainability conflict with those of economic imperatives, the latter must take precedence.

A view oppositional to that of the business case instead promotes an intensified interventionist approach towards natural resource management, advocating increased governmental regulation and control, including the mandating, standardization and independent verification of corporate sustainability reporting. This view gives precedence to public good concepts of natural resource management, prioritising intra- and inter-generational equity and human rights theories as to natural resource distribution, and challenges traditional economic approaches to the relational intersects of business, politics and environment science.

This paper considers the relative claims for efficacy in achieving desirable corporate environmental behaviours of the business case and voluntary self-regulation model, vis-à-vis those for extended mandatory governmental control, utilizing the exemplar of voluntary sustainability reporting in the New Zealand fishing industry.

Keywords: sustainability reporting; fishing industry; corporate social responsibility.

\section{Introduction}

A critical issue in the global management of natural resources, including fisheries, is attaining an optimal balance between the competing demands of national and international economic growth, and those of long-term species viability and eco-system sustainability (for example, Diamond, 2005; Clover, 2004). Fish stocks world-wide are under increasing pressure due to depletion from over-fishing, damage to marine eco-systems from destructive fishing practices, eutrophication and other forms of pollution, and changes in global climatic conditions.

The long-term sustainability of many fish species is in doubt, unless wide-scale and substantive changes to current industrialized fishing practices are implemented in the short term (Worm et al, 
The Australasian Accounting Business \& Finance Journal, September, 2008.

Wild: Sustainability Reporting in Fishing Industry Management. $\quad$ Vol. 2, No.3. Page 58.

2006; ELME, 2007; Pearce, 2003). Reports from governmental and other international bodies, including the United Nations Food and Agriculture Organization (UNFAO), the United Nations Environment Programme (UNEP), and the World Conservation Union (IUCN), as well as a range of independent researchers, have indicated the profound extent of ecological damage caused by unsustainable fishing practices, and its potential long-term economic and human consequences (for example, UNFAO, 1995; Gjerde, 2006; Gianni, 2004; Clover, 2004). Research indicates that $75 \%$ of global stocks are now utilized to at least their sustainable catch limits, with increasing acceleration in the rate of decline and increasing threat of species extinction. Extrapolation of current data illustrates that unless present trends are reversed within the short-term, no viable commercial fisheries world-wide will exist by the middle of the present century (Worm et al, 2006; Diamond, 2005, 498; Black, 7 December 2007.)

The application of sophisticated technologies and industrialized harvesting methods by national and multinational fishing enterprises, coupled with rapidly increasing global demand for fish as a food resource and for other utilizations, have already caused the complete collapse of some commercial fisheries, and threaten the survival of many others, particularly in the Atlantic, Mediterranean, and Pacific regions. With a growing number of traditional fisheries losing commercial viability, harvesting activity has been extended to formerly marginal areas, including the Antarctic region, and to the exploitation of previously neglected species. Fish stocks in nearly one-third of ocean fisheries have collapsed, and there is increasing acceleration in the rate of decline. The loss of the biological base of pelagic and demersal fish stocks worldwide is correlated with a broader loss of marine biodiversity, so that recovery to sustainable levels has a negative prognosis (Worm et al, 2006).

International governmental bodies, including those of the United Nations and the European Union, have been charged with the role of imposing a range of legal measures to achieve such a balance at a global and regional level, and to promoting cooperation amongst their member bodies. National governments, however, are confronted by the constraints of sector demands and strident political pressures to prioritise short-term policies promoting economic growth over those supporting long-term environmental sustainability, and competitive national political policies relating to food production and export (Diamond, 2005, 479-483; 487-488). Multilateral measures which are informed by, and support the praxis of, long-term sustainability of marine ecosystems, are confronted by the irreconcilable short-term economic demands of the commercial fishing industry, often supported by the expedients of competitive national political policies relating to food production and export (Anderton, 2008; Diamond, 2005, 479-483; 487488). In the case of the fishing industry, the principles of a market-driven economic model, responsive only to consumer and investor demand, are entirely incompatible with long-term sustainability of fish stocks.

\section{Corporate Social Responsibility and Sustainability Reporting}

Sustainability Reporting (SR) is promoted by its advocates as an appropriate motivational and regulatory tool to effect desirable corporate behaviours in social and environmental performance (for example, Gilkison, 1999; NZBCSD, 2002). Its promoters assert that voluntary SR is positively correlated with improved corporate environmental performance, and thereby displaces the necessity for externally-imposed regulation. It is suggested that stakeholder engagement in the processes of corporate decision-making can be influential in linking corporate disclosure of 
The Australasian Accounting Business \& Finance Journal, September, 2008.

Wild: Sustainability Reporting in Fishing Industry Management. $\quad$ Vol. 2, No.3. Page 59.

environmental impacts to the achievement of sound environmental practices, and that 'reporting influences performance, rather than just reflecting it' (Gilkison, 1999).

The set of financial, environmental and social information collectively provided under the rubric 'sustainability reporting' (SR) - variously labelled as social and environmental accounting (SEA), corporate responsibility reporting (CSR), sustainable development reporting (SDR), social responsibility reporting, and triple-bottom-line (TBL) reporting - has been informed by a number of diverse theoretical models, grounded on largely antithetical epistemological bases. These include the 'business-case', 'legitimacy theory', 'critical theory', and 'stakeholderaccountability' approaches (Brown and Fraser, 2004). Such reports vary extensively as to the nature and quality of the information provided, and in their target audience. The range of stakeholders referenced in this target group include, as in the case for traditional financial reports, stockholders and other investors, but may extend also to consumers, employees, suppliers, government agencies, non-governmental organizations (NGOs), and other `civil society' groups (Brown and Fraser, 2004; Deloitte, 2004).

The very wide range of variability evident in SR, and in the motivations driving the provision of such reports, reflects the wider societal dissension pertaining to the underlying concept 'sustainability', which, as a social construct, is itself a reflection of a variety of philosophical bases and differing perceptions, towards which there is little consensus between business and environmental organizations. (Deegan and Samkin, 2006, 1246; Pollock and Pretty, 2007).

At present, much non-economic corporate reporting, including reporting on environmental activity, is undertaken on a voluntaristic basis, and, in the absence of regulation for the standardization of such reports, it varies extensively in morphology and content. Suggested guidelines for the construction of such reports are provided by a number of agencies, both governmental and private. Currently, the most authoritative body providing guidance on reporting environmental and social information is the Global Reporting Initiative (GRI), established in 1987 as an international NGO under the auspices of the United Nations Environment Programme (UNEP). Also influential in improving the quality of sustainability reporting in both public and private sector organizations is the AA1000 series of assurance standards developed by AccountAbility, a London-based international not-for-profit association established in 1996 with the aim of 'promoting accountability for sustainable development' (AccountAbility website).

Professional accounting associations and standard-setting bodies internationally, including the International Accounting Standards Board (IASB), which are at the forefront of developing and administering standards and controls over mandatory external corporate financial reporting, have not initiated or supported the development of analogous standards and controls for reporting information on corporate reporting of environmental and social impacts. The role of such bodies continues to be limited to that of providing 'voluntary guidance' and suggested best practice on reporting of non-financial issues (Casey, 2005).

The self-disclosed motivations of individual corporations for voluntary reporting of social and environmental indicators commonly include enhancing corporate image and brand awareness, publicizing creditable ethical behaviours, meeting stakeholder expectations towards social responsibility beyond such achievements of competitors, and providing increased accountability 
and transparency regarding the environmental impacts of corporate activity (Warren, 2007). Independent analysts measuring the correlation between CSR and observed corporate environmental behaviours have, however, suggested a range of other self-interested drivers for provision of such information, including aims: '... to influence the perceived legitimacy of the organization; to manage particular (and possibly, powerful) stakeholder groups; to increase the wealth of shareholders and the managers of the organization; ... and to forestall efforts to introduce more onerous disclosure regulations.' (Deegan and Samkin, 2006, 1297-1315).

Although some countries are taking initiatives towards imposing additional requirements in regard to some limited external reporting of specific environmental performance indicators, in general these have been imposed only on public sector entities. In New Zealand, for example, all central and local government entities are obligated to report annually on a range of indicators of their environmental and social impacts, such as energy usage, waste management, and employment statistics, but at present there is no requirement for the provision of comprehensive sustainability reporting, in either the public or private sector.

Many business organizations, including Sustainable Business Networks worldwide, the International Chamber of Commerce (ICC), and most professional accounting associations, now encourage voluntary TBL or SR in some form as a sound business practice, and provide practical support and advice on how best it can be conducted. The prime reason that sustainability reporting and its variations are vigorously marketed by business organizations is that 'it is good for business' (Deegan and Samkin, 2006).

As well as enhancement of brand awareness and corporate reputation, the deflection of initiatives by government regulatory bodies to intervene in industry practices is a specific objective of business organizations such as the World Business Council for Sustainable Development (WBCSD) and the ICC for promoting the voluntary provision of sustainability reports and related environmental information. Such organizations promote the 'business case' for SR and CSR, that is, the concept that such behaviours should be pursued by corporations to the extent that they are financially profitable to do so (but not beyond that point). A keystone of the WBSCD policy is the promotion of economic growth.

\section{Voluntary SR and Corporate Environmental Performance}

Whilst a number of the major business and professional accounting organizations now present a generally supportive policy towards voluntary corporate sustainability reporting, there is a growing body of literature challenging the claims for a positive correlation between such reporting and improved environmental performance, and therefore challenging the notion of its efficacy as a useful tool for motivating desirable corporate behaviours. The disclosures presented in currently available sustainability reports are voluntary, selective, unregulated, unverified, and incomplete, and not reconciled to any reliable benchmarking system nor to actual organizational environmental performance.

It is claimed that, lacking neutral and authoritative verification, the majority of sustainability reports entirely lack credibility, and without recognized endorsement can be discounted for the purposes of meaningful evaluation or control of environmental behaviours. 'Greenwashing', the practice of promoting an image of social and environmental responsibility by emphasising superficial or incidentally sound activities whilst ignoring substantive environmentally negative 
The Australasian Accounting Business \& Finance Journal, September, 2008.

Wild: Sustainability Reporting in Fishing Industry Management. $\quad$ Vol. 2, No.3. Page 61.

practices, is widespread amongst those entities which are prominent in the movement promoting sustainability reporting as a voluntary, unregulated, corporate undertaking (Milne, Ball and Gray, 2005).

Most of the literature, when the basis of its analysis extends beyond a limited set of selected performance indicators, concludes that there is little or even negative correlation between the quality and extent of environmental reporting and measured actual environmental performance (Deegan and Rankin 1996; Hughes, Anderson and Golden, 2001; Patten, 2002; Milne and Ball, 2005). Milne and Ball (2005) suggest that TBLR 'may actually be illusory and lead to greater levels of un-sustainability' [original emphasis].

Gray and Milne (2002) point out the unreliability of the unregulated and non-mandatory nature of sustainability reporting that is favoured by business organizations:

[I]t seems to be in the nature of businesses to oppose in varying ways all forms of government "interference" - whether or not such "interference" is in the interests of society as a whole... the argument usually put against such interference - ie. against the regulation of corporate reporting - is that business organizations are best left to their own devices and voluntary regimes are always more effective. [However] [i]t is not as if we are to believe a business organization's financial success without the support of detailed and audited financial statements. Why then might we be expected to believe that the green rhetoric is to be believed without a similar quality of reporting and attestation? ... For a truly meaningful "triple bottom line" these social and environmental statements would be as important, detailed, rigorous and reliable as the financial statements.

Emphasising the fundamental contradictions for business organizations between wealthmaximization and environmental accountability, and between achieving economic growth and reducing a corporate's ecological footprint, Gray and Milne assert that 'there is an essential conflict between financial and other bottom lines which, for the foreseeable future at least, the financial will always win' (Gray and Milne, 2002). Jacquet and Pauly (2006) conclude that market-based initiatives alone are inadequate to effect the level of change that is necessary to ensure the ongoing application of sound corporate environmental behaviours, asserting that '[c]onsumers should not be misled that a system of management or conservation based on purchasing power alone will adequately address the present dilemma facing fisheries globally'. Their findings strongly support the view that reliance upon voluntary corporate initiatives cannot ensure ongoing sustainability in global fisheries, for which robust regulation, monitoring and enforcement are essential:

'Though fisheries regulations may need overhauling, they are needed, nonetheless. A citizen's strongest influence is ultimately his/her engagement in the democratic process and the election of governments committed to fisheries management through curtailing overcapacity, abolishing flags of convenience, strengthening regulations, and ensuring traceability' (Jacquet and Pauly, 2006).

The implications of this model emphasise the limitations of the 'business case' for sustainability reporting, and the fundamental irreconcilability of the 'entity' concept of accounting with the societal emphasis of sustainability. A number of environmental analysts have critiqued the inadequacies of traditional economic models to account for the qualitative concepts 
The Australasian Accounting Business \& Finance Journal, September, 2008.

Wild: Sustainability Reporting in Fishing Industry Management. $\quad$ Vol. 2, No.3. Page 62.

encompassed within the collectivist, internationalist, and inter-generational values of sustainability, for example its entire failure to address non-market measures of habitat destruction, species extinction and depletion of aesthetic quality (The Economist, 1998). Such critiques also address the interconnected, multifaceted and highly complex nature of environmental sustainability, a concept which 'involves levels of analysis and complexity that go well beyond the impacts of single organizational entities’ Gray and Milne (2002).

\section{New Zealand's Fishing Industry - a Sustainable Future?}

Throughout its history, New Zealand's fishing industry has been of major importance to its economy. The country's ocean and freshwater seafood comprise an important Taonga (treasure), referenced in New Zealand's founding document, the Treaty of Waitangi, signed in 1840 between indigenous Maori tribes and the British Crown. Now, with a total population of approximately 4.3 million, the country controls the world's fourth largest fishing zone, its fisheries contributing more than $\$ 1.3$ billion in export earnings, employment for more than 10,000 workers, and an increasingly important component of the national diet (New Zealand Ministry of Fisheries \{MFish\}, 2006). New Zealand's principal markets for fish products are Japan, the United States, Australia, Europe (mainly France and the UK), and other Asian countries including China, Korea, Hong Kong, Singapore, Taiwan, and Thailand, with the main export species comprising orange roughy, rock lobster, squid, hoki and snapper, as well as shellfish including paua (abalone), oysters, mussels and scallops (MFish, 2006).

Management of New Zealand's marine areas is the statutory responsibility of the Ministry of Fisheries (MFish). This government body is also responsible for advising government and developing policies for the sustainable utilization of fisheries, administering relevant regulations, supporting marine science research, and facilitating export markets at a governmental level. The Ministry also gives effect to the principles of the Treaty of Waitangi as they relate to the rights of the country's indigenous Maori population in regard to fish resources, and administers the Quota Management System (QMS) that regulates New Zealand commercial fishing activity (MFish, 2006).

In 1978, the New Zealand government imposed a 200 nautical mile Exclusive Economic Zone (EEZ), extending for 3.37 million square kilometres, claiming exclusive management of all fisheries and other marine life within this zone. Within this region, the activity of non-New Zealand fishing vessels is largely excluded (although, as in other regions globally, fishing piracy presents ongoing concerns to government monitoring and enforcement agencies). The major tool in the management of New Zealand's fishing resources within its EEZ, intended to prevent overfishing and assist in conservation of fish stocks, is the implementation of the Quota Management System, which imposes transferable quotas setting maximum catch limits - Total Allowable Commercial Catches (TACCs) - on specific commercial species in specific areas. Commercial fishers must hold Annual Catch Entitlement (ACE) permitting them to harvest species up to the maximum limit set. TACCs are reviewed periodically, based on consultation with industry representatives and fisheries researchers, with maximum seasonal catch levels set and subjected to ongoing monitoring and adjustment. Within New Zealand waters, 130 species are fished commercially, and 94 of these are regulated under the QMS (MFish, 2006).

For New Zealand's major fishing companies, including Sanford, Sealord, Talleys/Amaltal, and the Orange Roughy Management Company, competitive commercial interests have been the 
The Australasian Accounting Business \& Finance Journal, September, 2008.

Wild: Sustainability Reporting in Fishing Industry Management. $\quad$ Vol. 2, No.3. Page 63.

overriding drivers for setting their policies regarding environmental concerns. In 2006 these companies were among vigorous lobbyists against New Zealand government support for a proposed United Nations international moratorium on bottom trawling and other highly destructive practices in the South Pacific and Southern Ocean regions, which would include provisions for international cooperation in robust monitoring, control and surveillance (SPRFMO, 2006).

New Zealand's commercial fishing industry conducts $90 \%$ of bottom trawling activities in the South Pacific high seas (Greenpeace, 'Oceans', 2006). Since 2001, against strong and ongoing opposition from the industry, the New Zealand government has closed nineteen deep-water seamount areas against all trawling, after scientific reports of major destruction to vulnerable marine eco-systems, and has created a range of marine reserves, in which commercial fishing is restricted. Strong government action became essential after a commitment by the fishing industry to implement voluntary controls failed to achieve the responses required by the Ministry of Fisheries, and in 2006, bottom-trawling activity was banned in a third of the country's offshore waters, against determined industry opposition (Dover, 2006).

In December 2006, in response to the ongoing level of loss of bycatch species resulting from environmentally-unfriendly fishing methods and poor compliance with voluntary constraints, government-imposed emergency measures enforced a temporary closure of the country's commercial swordfish operation (NZ Herald, 29 January, 2007). The precipitating factor for this action was bycatch of a single vessel comprising 51 rare Antipodean Albatrosses, seven petrels and two critically endangered leatherback turtles. While swordfish along with most other commercial fish species have been included under the quota management system (QMS), this has provided no protection from losses of marine birds and other creatures caused by long-lining methods of fish harvesting. Endangered Hectors Dolphins, as well as other marine mammals, are also at ongoing risk from set-netting and other wasteful and indiscriminate fishing practices.

Despite the management of New Zealand fisheries under the provisions of the Quota Management System (QMS), which is intended to ensure that catch volumes do not exceed sustainable levels, a number of species have experienced severe decline in population and in several areas have collapsed below commercial viability, including important commercial species such as Orange Roughy which, due principally to over-fishing, suffered decline in catch numbers of 60\% between 2001 and 2005 (MFish, 2006). hoki, New Zealand's major export species with earnings of $\$ 156$ million in 2006, was certified by the London-based Marine Stewardship Council (MSC) in 2001 as one of only a small number of fisheries globally to be ecologically 'sustainable and well-managed' (Marine Stewardship Council). The MSC endorsement has enabled the New Zealand industry to increase its sales in additional market areas, including to the McDonalds chain, which now requires its fish products to be sourced from such eco-certified providers.

Since 2001, however, New Zealand hoki numbers have continued to experience critical decline due to the combined effects of overfishing, destructive harvesting practices and environmental change affecting reproduction capacity. The TACC numbers for hoki have been reduced successively from 250,000 tonnes in 2001 to a planned 80,000 tonnes in 2007/08, in an effort to arrest the ongoing sharp decline in assessed stock levels (Burgess, 2007). In September 2007 the New Zealand government again reduced the catch limits in some key fisheries, including hoki, in 
The Australasian Accounting Business \& Finance Journal, September, 2008.

Wild: Sustainability Reporting in Fishing Industry Management. $\quad$ Vol. 2, No.3. Page 64.

an attempt to arrest the ongoing decline in fish stocks of some of the country's key commercial fisheries, with hoki limits being cut by a further $10 \%$, orange roughy $28 \%$, and South Island red cod by 63\%. In the same month, the MSC renewed its eco-certification for New Zealand's hoki fishery (MSC website, 2007), confirming its categorisation as 'sustainable', despite strong opposition from conservation groups, particularly WWF and the Royal Forest and Bird Protection Society of NZ, (Forest and Bird NZ). The MSC's Independent Objections Panel, upheld the MSC decision under the narrow grounds of the appeal procedures, but concluded that the fishery received a passing score only 'by the skin of its teeth', citing serious concerns as to the future sustainability of the hoki fishery due to issues including inadequate and unreliable research availability (Report of Independent Objections Panel, MSC website, September 2007). Strongly disparate views as to the reliability of such eco-certification were expressed by fishing industry representatives and environmental groups.

\section{Sustainability Reporting in the New Zealand Fishing Industry}

All New Zealand's major fishing companies, including Sanford, Sealord, Talleys/Amalta, and the Orange Roughy Management Company, provide assertions in their various publications, both hardcopy and electronic, regarding the environmental impacts of their activities. These include statements of their strong commitment to upholding principles of sustainability in their own practices and in those of the fishing industry generally, and pledges of support for the wider concepts of corporate social responsibility.

Sanford, which in its publications styles itself as being a provider of 'Sustainable Seafood', asserts its commitment to 'industry responsibilities', compliance with environmental regulations, to 'continually investigating the implementation of methods to improve the Company's ecoefficiency in terms of farmed and harvested seafood, energy, water, packaging and waste management', the implementation of an environmental management programme, 'protecting and enhancing the natural environment through active management programs', 'responsibility to international stakeholders', and general 'environmental awareness'. It claims that 'the Company supports the sustainable utilization of seafood from new Zealand's unique marine environment, and in other waters in which the company operates. We seek to act responsibly in our commercial operations in accordance with international best practice'. The company further asserts that its activities are fully compliant with 'all reporting requirements of CCAMLR [1982 Convention for the Conservation of Antarctic Marine Living Resources], the New Zealand Government and other international bodies' (Sanford Ltd website).

Sanford publishes an extensive 'Sustainable Development Report', which asserts inter alia that the company is 'operating in a socially responsible manner'. This report is accompanied by an 'Assurance Statement' provided by private assurance company URL (this does not, however, provide the level of verification required of its financial reports, the requirements for contents and auditing of which are imposed, standardized and enforced by legislation). Sanford has consistently received commendations for the quality of its environmental reporting at the annual awards presented by the New Zealand Institute of Chartered Accountants (NZICA).

Sealord is a major New Zealand-based fishing company owned jointly by tribes of New Zealand's indigenous Maori people and Japanese company Nippon Suisan Kaisha (Nissui), a $50 \%$ shareholder. The company holds approximately $21 \%$ of New Zealand's quota of fish stocks under the QMS, and has global interests in fishing, processing and marketing, as well as 
engaging in joint ventures and associations with a range of overseas seafood companies. The published statements of the company claim that '[c]are for the environment is one of Sealord's core values' ... we recognise our responsibility to ensure there are fish for the future, by fishing sustainably. W]e seek to reduce our impact on the environment and actively look for environmentally friendly ways of carrying out our business' , '[w] are committed to fishing in a sustainable way'. The company asserts its commitment to an engagement in improvement and monitoring of fishing standards and conducting research on fish stocks, noting as a specific policy that it has 'taken steps towards' protecting dolphins and seabirds.

Sealord's parent company, Nissui, (which is also 100\% owner of major US seafood company Gortons), was until early 2006 a one-third shareholder of Kyodo Senpaku, which operates the Japanese whaling fleet (Greenpeace, 2006). Over an extensive period, Nissui has operated whalemeat harvesting, canning and distribution enterprises, and its executives have been strong lobbyists at the International Whaling Commission (IWC) against restrictions on commercial whaling. Sealord's senior executives defended Nissui's activities, but following a publicity campaign and boycott by environmental activists, including Greenpeace, which posed a threat to its group's market share and profits, Nissui divested itself of its shareholding in its whaling operations, and Sealord mounted a vigorous public relations exercise to restore its negative image with its consumers.

Talleys/Amaltal is a privately-owned New Zealand fishing company that owns significant quota rights and operates a fleet of inshore and deep water fishing vessels, as well as undertaking involvement in other commercial marine activities including provedoring. The company operates both inshore and deep-sea fishing fleets under the QMS, as well as receiving supply from private, independently-contracted fishing vessels, both New Zealand and foreign-based, its principal catch species including hoki, red cod, squid, orange roughy, toothfish, and tuna. In its published information, the company states that it takes 'significant responsibility for the sustainable management of New Zealand's seafood resources and the future of the fishing industry (Talleys website). Amaltal, however, strongly opposed the implementation of regional restrictions on bottom-trawling in 2006 (Dover, 2006).

The Orange Roughy Management Company operates the largest fishery of orange roughy globally, and asserts in its publications to operate in accordance with principles of sustainability and in a manner compliant with New Zealand fisheries regulations under the QMS. The Company pledges its support for the practice of the QMS system, asserting that this model 'provides economically rational methods of fishing', and presents the business case for sustainability, suggesting that the goal of profit-maximisation is fully compatible with sound environmental principles. However, in 2006, the company joined the fishing industry lobby against New Zealand government support for a moratorium on bottom trawling to allow fish stock recovery, and resists further closures of marine areas to this practice (NZ Herald, 17 June 2005). In January 2008, in response to the New Zealand Ministry of Fisheries' attempt to reduce the 2008 TAC for orange roughy as a precautionary approach in consideration of the limited information available to establish the accuracy of sustainable harvest limits, several New Zealand fishing companies took successful action in the High Court blocking the action. The industry has also successfully lobbied against government plans promoted in 2006 to introduce fisheries legislation supporting a cautious approach in favour of sustainability when there is little or poor available information regarding the status of fish stocks. 


\section{Conclusions}

Despite the published assertions of the major protagonists in New Zealand's fishing industry of their commitment to the principles and practice of environmental sustainability, the country's fisheries reflect the deteriorating status of those worldwide. Research conducted by non-industry analysts has disclosed that New Zealand's orange roughy fishery is the most threatened, with stocks of hoki, the country's most important species commercially, now displaying a critical decline in number. Of the country's more than 60 marine fisheries, approximately half are considered unsustainable under present fishing practices, due to overfishing, poor management, excessive bycatch, ongoing damage to marine habitats, and failure to adequately monitor and assess biomass levels (Royal Forest and Bird Protection Society of NZ, (Forest and Bird NZ), 2005).

Sustainability reporting on a non-mandatory basis, in these circumstances, is commonly appropriated as a tool in service of the fundamental business imperative of profit-maximization, rather than functioning to effect accountability and improved environmental behaviours through the mechanism of ensuring transparency and completeness of information to consumers, stockholders, government agencies, and other stakeholders in regard to the environmental impacts of corporate operations. Research conducted by the global marine programme at the World Conservation Union (IUCN), has shown that the most effective measure in arresting decline in fish stocks has been government intervention to severely curtail fishing activities, or to close fisheries altogether, to allow recovery to take place over time. The research indicates that significant improvement in fish stocks, and in biodiversity generally, is achieved within, and in areas closely contiguous to, marine reserves and prohibited catch zones (IUCN, 2006; Black, 2006). These results are mirrored in the New Zealand data, and form the basis for current government fisheries policy (Ministry of Fisheries website; Greenpeace, 'Oceans', 2006)

Although all major New Zealand fishing corporations in their publications express their support for the principles of sustainability and sound environmental management, it has been demonstrated that this has been largely ineffectual in preventing harvesting practices contributing to a severe decline in New Zealand's fish stocks over recent decades. Sustainability reporting in its present voluntaristic, non-standardised and unverified form has proved to be ineffectual and even counter-effective in ensuring desirable corporate environmental behaviours. The 'business case' for corporations to endorse sustainable practices is subject to the general legal requirement of those responsible for corporate governance that the resources of entities are utilized for the purpose of maximising the wealth of shareholders. This is consistent with the fundamental tenet of business that all activity must create a required return on invested capital within a commercial time-frame, that is, in the short term. In this view, any undertakings consistent with the objectives of social and environmental responsibility must not be inconsistent with these basic requirements of business. Friedmanite economic theorists, for example, whose philosophies regarding the nature of commerce have been strongly influential in establishing the policies and values of business organizations internationally, assert that 'there is one and only one social responsibility of business - to use its resources and engage in activities designed to increase its profits so long as it stays within the rules of the game ...' (Friedman, 1962).

It may be concluded therefore, that in order that these apparently fundamental requirements of business can continue to be met whilst the requirements of environmental sustainability are also 
The Australasian Accounting Business \& Finance Journal, September, 2008.

Wild: Sustainability Reporting in Fishing Industry Management. $\quad$ Vol. 2, No.3. Page 67.

to be pursued, it will be necessary for national and international governments to change 'the rules of the game'. Research demonstrates that long-term sustainable management of natural resources such as fish stocks can be achieved only through international and regional government cooperation, by means of the implementation and effective monitoring and enforcement of appropriate regulation, based upon independent and objective scientific evaluation of ecosystem conditions.

This strategic approach requires the imposition of limitations on the regions, methods, timing, catch size and species allowable for commercial fishing, together with elimination of subsidies, with economic considerations and industry demands being subject to, rather than the determinant of, such measures towards long-term resource sustainability. Also advantageous would be the adoption of a general shift in fishing industry economic policy, away from the concept of Maximum Sustainable Yield (MSY), the traditional quantification of highest allowable harvesting levels, to a more supportable model such as Maximum Economic Yield (MEY), based on cost-minimisation targets supporting catch limitation to promote fish stock regeneration. In addition to such interventions aimed at placing limitations on supply, there is now also a critical requirement to move to full pricing systems (incorporating all externalities including environmental costs), together with ongoing consumer education and other measures aimed at reducing commercial demand for utilization of scarce and endangered natural resources.

\section{References}

Abbott, W.F. and Monsen, R.J. (1979). 'On the Measurement of Corporate Social Responsibility: Self-reported Disclosures as a Method of Measuring Corporate Social Involvement', in Academy of Management Journal, 22 (3), 501-515. https://doi.org/10.5465/255740

AccountAbility, Institute of Social and Ethical Accountability. AA1000 Assurance Standards. Accessed 18 May, 2007 on website: http://www.accountability21.net .

Anderton, J. (22 February, 2008). 'Response to Antons court case ruling'. Accessed 1 March 2008 from Beehive New Zealand Government website: http://www/beehive.govt.nz/release/response+antons+court+case+ruling

Baskerville, R. (2001). 'Organizing for Sustainability’, in New Zealand Chartered Accountants Journal, December 2001, 32.

BBC News (24 November, 2006). 'Ban on “brutal” fishing blocked”. Accessed 25 November, 2006, on website: http://newsvote.bbc.co.uk/mpapps/pagetools/print/news.bbc.co.uk/2/hi/science/nature/

BBC News (5 May, 2007). 'South Pacific to Stop Bottom Trawling'. Accessed 6 May, 2007, on website: http://www.bbc.co.uk/

BBC News (19 September, 2007). 'Europe bans bluefin tuna fishing'. Accessed 20 September 2007, on website: http://www.bbc.co.uk/

Beston, A. (2006). 'Sea-bottom pics reveal destruction', in The New Zealand Herald, 13 February, 2006. Accessed 14 February, 2006, on website: http://www.nzherald.co.nz

Black, R. (2 November 2006). 'Only 50 years left for sea fish'. Accessed 7 November, 2006, on website: http://www.bbc.co.uk/.

Brown, J, and Fraser, M. (2004). `Competing Discourses in Social and Environmental Accounting: An Overview of the Conceptual Landscape’. Wellington, New Zealand: Centre for Accounting, Governance and Taxation Research, Victoria University of Wellington, Working Paper Number 12.

Brown, J. and Fraser, M. (August 2004). 'Social and Environmental Accounting: How Are You approaching It? Part One: The Business Case Approach’. in New Zealand Chartered Accountants Journal, 16-20.

Brown, J., and Fraser, M. (September 2004). `Social and Environmental Accounting: How Are You approaching It? Part Two: The Stakeholder-accountability, and Critical Theory Approaches'. in New Zealand Chartered Accountants Journal, 24-28.

Brown, P. (2004). ‘Crisis of credibility for “green” fisheries’. Article in The Guardian, 21 February 2004. Accessed 12 May 2007 on website: http://www.guardian.co.uk 
The Australasian Accounting Business \& Finance Journal, September, 2008.

Wild: Sustainability Reporting in Fishing Industry Management.

Vol. 2, No.3. Page 70.

Brundtland Report (1987). Report of the United Nations World Commission on Environment and Development. Accessed 12 May 2007, on website: un.org/documents/ga.res/42/ares42-187.htm.net

Burgess, M. (2007). 'Big fisheries call for sharp hoki quota cut', in The New Zealand Herald ,(9 July, 2007).

Accessed 10 July 2007 on website: http://www.nzherald.co.nz/section/story.cfm

Casey, P. (August 2005) “Reporting beyond the numbers', in New Zealand Chartered Accountants Journal. 6-7.

Clover, C. (2004). The End of the Line: How Overfishing is Changing the World and What We Eat. Ebury Press.

Corporate Register. Accessed 15 May 2007 at website: http://www.corporateregister.com

Corporate Social Responsibility Reports. Ethics World. Accessed 15 May 2007 at website: http://www.ethicsworld.org/corporatesocialresponsibility.corporatecsrreports

Deegan, C. (2002). 'The legitimising effect of social and environmental disclosures - a theoretical foundation', in Accounting, Auditing and Accountability, 15(3), 282-311.

Deegan, C., and Samkin, G. (2006). Accounting For Corporate Social Responsibility', chapter in New Zealand Financial Accounting (3 ed). Auckland, New Zealand, McGraw-Hill. 1244-1329.

Deep Sea Conservation Coalition. Website: http://www.savethehighseas/org

Deere, C. L. (1999). Eco-labelling and sustainable Fisheries. World Conservation Union (IUCN) publication. Gland, Switzerland: IUCN.

Deloitte. (2004). Benefits of Sustainability Reporting. Accessed 9 September, 2004, from website: www.deloitte.co.nz

Diamond, J. (2005). Collapse: How Societies Choose to Fail or Survive. London, England: Penguin Books.

Dover, M. (2006). '”Destructive fishing” ban for NZ', in BBC News, 21 February 2006. Accessed on website: http://www.bbc.co.uk

Economist, The. 18 April 1998, 77. Editorial. https://doi.org/10.1016/S0921-8181(98)00006-X

European Commission (EC) Common Fisheries Policy (CFP). Accessed 10 May 2007 on website: http://ec.europa.en/fisheries/cfp_en.htm

European Lifestyles and Marine Ecosystems (ELME). Exploring Challenges for Managing Europe’s Seas. Accessed 10 June 2007 on website: http://www.elme-eu.org/

Frame, B., McGuinness, W., and Gordon, R. (2003). 'Reinforcing a Clean Green Brand: An Overview of Sustainable Development Reporting in New Zealand' , in Accountability Quarterly 23, 23-28.

Friedman, M. (1962). Capitalism and Freedom. University of Chicago Press, Chicago, US.

Friedman, M. (1970). ‘The Social Responsibility of Business is to Increase its Profits', article in The New York Times Magazine, 13 September, 1970.

Gianni, M. (2004). High Seas Bottom Trawl Fisheries and their Impact on the Biodiversity of Vulnerable Deep-Sea Ecosystems. World Conservation Union (IUCN)/ International Action publication. Gland, Switzerland: IUCN.

Gilkison, B. (1999). Accounting for a Clean, Green Environment: Obligations and Opportunities for New Zealand Businesses and their Accountants. Motueka, New Zealand: KPMG.

Gjerde, K. M. (2006). 'Ecosystems and Biodiversity in Deep Waters and High Seas'. UNEP Regional Seas Reports and Studies. $\quad$ No.178, June 2006. Gland, Switzerland:UNEP/IUCN. Accessed 11 November 2006 from website: http://www.iucn.org/THEMES/MARINE/pubs/pubs.htm

Gray, R., Bebbington, J., and Walters, D.. (1993). Accounting for the Environment. Princeton, New Jersey, US: Markus Wiener Publishers; and London, UK: Paul Chapman Publishers Ltd.

Gray, R., and Milne, M. J. (2002). 'Sustainability Reporting: Who’s Kidding Whom? ‘. Discussion Paper for CSEAR Conference. Accessed 3 January 2007 from: http://www.st-andrews.ac.uk/ csearweb/researchresources/dpssustain-whoskidding.html.

Greenpeace (2006). “Oceans’. Accessed 22 November 2006, from website: http://greenpeace.org/en/ouroceans/bycatch.

Henderson, D. (2001). 'Misguided Virtue: Failed Notions of Corporate Social Responsibility'. New Zealand Business Round Table (NZBRT), June 2001. Accessed 18 May 2007 on website: http://www.nzbr.org.nz

Hughes, S.B., Anderson, A., and Golden, S. (2001), "Corporate environmental disclosures: are they useful in determining environmental performance?", Journal of Accounting \& Public Policy, Vol. 3 No.20. 217-40. https://doi.org/10.1016/S0278-4254(01)00031-X

International Commission for the Conservation of Atlantic Tunal (ICCAT). Website: http:intfish.net/orgs/fisheries/iccat.htm

IUCN (2006). 'Ocean Oases: Returns on Investing in a Global System of Marine Protected Areas'. Briefing Paper for the World Economic Forum 2006. Accessed 11 November 2006, from website: http://www.iucn.org/THEMES/MARINE/pubs/pubs.htm 
The Australasian Accounting Business \& Finance Journal, September, 2008.

Wild: Sustainability Reporting in Fishing Industry Management.

Vol. 2, No.3. Page 71.

Jacquet, J. L, and Pauly, D. (2006). 'The rise of seafood awareness campaigns in an era of collapsing fisheries', in ScienceDirect, 14 September 2006. Accessed 12 April 2007, from website: www.sciencedirect.com. https://doi.org/10.1016/j.marpol.2006.09.003

Kearins, K. (2004). 'Making sense out of mixed meanings'. Article in Chartered Accountants Journal (February, 2004). 62-63.

Kerr, R. (1996). 'Does business have a social responsibility?’. Article in The Independent, 13 December, 1996.

Marine Conservation Society (MCS). Website: http://www.mcsuk.org

Marine Stewardship Council (MSC) Report of Independent Objections Panel. (September 2007). Accessed 23 September 2007, from MSC website: http://www.msc.org

Milne, M., Ball, A., and Gray, B. (2005). `From Soothing Palliatives and Towards Ecological Literacy: A Critique of the Triple Bottom Line'. Paper presented at the $16^{\text {th }}$ International conference on Social and Environmental Accounting Research (4 ${ }^{\text {th }}$ Australasian CSEAR), 30 March -1 April, 2005. Deakin Management Centre, Deakin University, Geelong, Victoria, Australia.

Milne, M, and Ball, A. (2005). Business and Sustainability: Agenda for Change or Soothing Palliatives? Paper presented at Research Seminar Series, Victoria University of Wellington, 18 March 2005.

New Zealand Business Council for Sustainable Development (NZBCSD) (2002). Business Guide to Sustainable Development Reporting: Making a Difference for a Sustainable New Zealand. October 2002.

New Zealand Business Round Table (NZBRT). Website: http://www.nzbr.org.nz

New Zealand Herald. (29 January, 2007). 'Longlines banned during day in bid to save albatross'. Accessed on 30 January 2007 on website: http://www.nzherald.co.nz

New Zealand Herald. (17 June, 2005). 'Deep sea trawl ban would hit Nelson hard, say industry figures'. Accessed on 2 August 2006 on website: http://www.nzherald.co.nz

New Zealand Institute of Chartered Accountants (NZICA). Website: http://nzica.co.nz

New Zealand Ministry of Fisheries (MFish). Website: http://www.fish.govt.nz/

New Zealand Ministry of Fisheries (MFish). (2006). Economics fact sheet: why the fishing industry is important to New Zealand. Accessed 2 August 2006 from website: http://www.starfish.govt.nz/economic/facts/fact-whyimpt.htm.

Patten, D.M. (1991), "Exposure, legitimacy, and social disclosure", Journal of Accounting \& Public Policy, Vol. 10, No.4. 297-308. https://doi.org/10.1016/0278-4254(91)90003-3

Pearce, F. (2003). 'Oceans Raped of Their Former Riches'. Article in NewScientist, 2 August, 2003. 4-5.

Pinkerton, M., and Livingston, M. (2006). ‘Trophic modelling for sustainable New Zealand Fisheries'. Accessed 2 August 2006 from NIWA Science website: http://www.niwascience.co.nz/pubs/wa/12-2/trophic.

Pollock, C., and Pretty, J. (2007). 'Pastures New'. Article in NewScientist, 21 April, 2007. P18. https://doi.org/10.1016/S0262-4079(07)60975-0

Richardson, M. (2004). 'Ocean-roaming birds under threat'. Article in New Zealand Herald, 9 October, 2004. Accessed 12 May 2007 on website: http://www.nzherald.co.nz

Royal Forest and Bird Protection Society of NZ (Forest and Bird NZ). (2005). Seafood Industry Conference Media Release. (18 may 2005). Accessed on 22 November 2006 on website: http://www.forestandbird.org.nz/mediarelease/2005.

Royal Forest and Bird Protection Society of New Zealand (Forest and Bird NZ), Accessed 2 February, 2007 on website: http://www.forestandbird.org.nz.

Sanford Ltd website: http://www.sanford.co.nz

Sealord Group Ltd website: http://www.sealord.co.nz.

South Pacific Regional Fisheries Management Organisation (SPRFMO) 2006 Report. (2006). Accessed 6 May 2007 on website: http://www.southpacificrfmo.org/mainsite/event.first-meeting

Talley’s Group Ltd website: http://www.talleys.co.nz

Thompson, W. (2006) “Our fisheries are in good shape, says Minister'. Article in The New Zealand Herald , 4 November 2006. Accessed 6 November 2006 on website: http://www.nzherald.co.nz

United Nations Environment Programme (UNEP). Website: http://www.unep.org

United Nations Food and Agriculture Organization (UNFAO). Website: http://www.fao.org

United Nations Informal Consultative Process on Oceans and the Law of the Sea (UNICP). Website: http://www.un.org/depts/los/consultative_process/consultative_process.htm

United Nations/World Commission on Environment and Development (WCED). Website: http:// Brundtland Report

Van Staden, C, and Hooks, J. (2005). Greenwash or Accountability: the correlation between environmental responsiveness and environmental reporting in New Zealand. Paper presented at School of Accountancy Research Seminar, Massey University, Wellington, New Zealand, 14 September 2005.

Warren, M. (2007). 'Sustainability in Shades of Green', in The Australian, 6 August, 2007. Accessed 7 August 2007, on website: http://theaustralian.news.com.au/story/0,,22193427-23850.00.html?from=public

Washington DC Sustainable Business Network. Website: http://www.dcsbn.org

World Business Council for Sustainable Development (WBCSD). Website: http://www.wbcsd.org 
The Australasian Accounting Business \& Finance Journal, September, 2008. Wild: Sustainability Reporting in Fishing Industry Management.

Vol. 2, No.3. Page 72.

World Conservation Union, The (IUCN). Website: http://www.iucn.org

World Wide Fund for Nature (WWF). Website: http://www.wwf.org

Worm, B.; Barbier,E.B. ;Beaumont, N; Duffy. J.E. ; Folke,C; Halpern, B.S.; Jackson, J. B. S.; Lotze, H.K.; Micheli, F.; Palumbi, S.R.; Sala, E.; Selkoe, K.A.; Stachowicz, J.J.; and Watson, R. (2006). 'Impacts of Biodiversity Loss on Ocean Ecosystem Services’ in Science (3 November, 2006), Volume 314, Number 5800, 787-790. https://doi.org/10.1126/science.1132294 